\title{
STUDI DESKRIPTIF KUALITATIF: PERSEPSI REMAJA TERHADAP PERILAKU MENYIMPANG
}

\author{
Zulkhairi $^{1}$, Arneliwati ${ }^{2}$, Sofiana Nurchayati ${ }^{3}$ \\ ${ }^{1,2,3}$ PSIK Universitas Riau \\ Program Studi Ilmu Keperawatan Universitas Riau Jalan Pattimura No 9 Gedung G Pekanbaru Riau \\ Kode Pos 28131 Indonesia \\ Email: zkhairi12@gmail.com
}

\begin{abstract}
Abstrak
Remaja merupakan sosok yang dikenal dengan rasa ingin tahu yang besar dan dalam proses mencari identitas diri sehingga sangat berisiko untuk terjerumus kedalam perilaku menyimpang. Penelitian ini bertujuan untuk mengetahui gambaran persepsi remaja terhadap perilaku menyimpang. Penelitian ini menggunakan desain deskriprif kualitatif. Partisipan yang didapatkan dalam penelitian ini berjumlah 4 orang (2 orang siswa dan 2 orang siswi) dengan menggunakan teknik purposive sampling sesuai dengan kriteria inklusi. Penelitian ini dilakukan di SMA Tri Bhakti Pekanbaru dengan menggunakan pedoman wawancara. Analisa yang dilakukan adalah analisa interaktif. Hasil penelitian ini menemukan gambaran dari persepsi remaja dan pengetahuan remaja terhadap perilaku menyimpang berdasarkan pertanyaan yang peneliti sampaikan. Hasil penelitian ini partisipan memberikan gambaran tentang fenomena perilaku menyimpang saat sekarang ini berdasarkan dari sudut pandang partisipan sebagai seorang remaja, perilaku menyimpang merupakan perilaku yang tidak baik dan sangat memprihatinkan, dapat merugikan diri sendiri dan orang lain, atau bersifat negatif. Partisipan juga memiliki pengetahuan yang baik terhadap perilaku menyimpang. Hasil penelitian ini diharapkan dapat digunakan bagi tenaga kesehatan dan tenaga pendidikan sebagai edukator dan konselor dalam memberikan edukasi pada remaja serta masyarakat untuk membantu remaja dalam mengatasi perilaku menyimpang di lingkungan sosial.
\end{abstract}

Kata kunci: Perilaku menyimpang, persepsi, remaja

\begin{abstract}
Adolescents are people who have high curiosity and in the process of looking for identity so that it has a risk to perform deviant behaviour. This research aimed to determine the description of adolescent perceptions of deviant behavior. The design of this research uses qualitative descriptive design. Participants obtained in this study amounted to 4 people (2 females and 2 males) by using purposive sampling technique in accordance with inclusion criteria. This research was conducted in SMA Tri Bhakti Pekanbaru. This research uses interview guidelines. The analysis is a interactive analysis. The results of this study found a picture of adolescent perceptions and adolescent knowledge of deviant behavior based on questions that researchers convey. From the results of this study participants gave a description of the phenomenon of deviant behavior now based on the perspective of participants as a teenager, deviant behavior is a bad behavior and very concerned, can harm yourself and others, or are negative. Participants also have a good knowledge of deviant behavior. The results of this study are expected to be used for health workers and education personnel as educators and counselors in providing education to adolescents and communities to help adolescents in overcoming deviant behavior in the social environment.
\end{abstract}

Keywords: Deviant behaviour, perception, adolescent

\section{PENDAHULUAN}

World Health Organisation (WHO,

2014) mendefinisikan remaja adalah penduduk dalam rentang usia 10 sampai 19 tahun sedangkan menurut Badan Kependudukan dan Keluarga Berencana (BKKBN) dalam (Pusdatin Kemenkes RI, 2015) remaja adalah rentang usia 10-24 tahun dan belum menikah. 
Zulkhairi $^{1}$, Arneliwati ${ }^{2}$, Sofiana Nurchayati $^{3}$,Studi Deskriptif Kualitatif: Persepsi Remaja Terhadap Perilaku Menyimpang

Perkiraan kelompok usia remaja di dunia berjumlah 1.2 miliyar atau $18 \%$ dari jumlah penduduk dunia (WHO, 2014). Jumlah remaja di Indonesia sekitar 44.5 juta (Kemenkes RI, 2015). Remaja di provinsi Riau diperkirakan berjumlah 1.1 juta remaja (Dinkes Provinsi Riau, 2014) dan jumlah anak usia remaja di kota Pekanbaru diperkirakan sekitar 193.467 jiwa menurut Dinas Kesehatan Kota Pekanbaru (Dinkes Kota Pekanbaru, 2014).

Besarnya jumlah remaja di Indonesia semakin menambah besarnya jumlah tantangan yang ditimbulkan oleh remaja sebagai akibat dari kompleksnya permasalahan pada masa transisi remaja. Adanya peningkatan dorongan seksual dan perubahan yang alami terjadi pada masa remaja terkadang menimbulkan masalah yang cukup serius (Haryanto \& Suarayasa, 2013) dalam (Widanarti \& Nashori, 2015). Soetjiningsih, (2010) mengatakan bahwa pada masa ini timbulnya ciri-ciri seks sekunder, tercapai fertilitas dan terjadi perubahan-perubahan secara fisiologis, psikologik, psikososial serta kognitif. Masa ini menjadi persoalan yang sulit bagi remaja, karena remaja berada dalam suatu hal yang membingungkan, di satu sisi ia masih anak-anak di sisi lain ia harus berperilaku seperti orang dewasa (Sarwono, 2014).

$$
\text { Al-Bahra dan Efgivia }
$$
menyebutkan remaja dikenal sebagai sosok dengan rasa ingin tahu yang sangat besar dan pada masa ini, remaja sedang dalam proses mencari identitas, mencoba sesuatu yang baru dalam dirinya. Remaja mulai meniru-niru sesuatu yang menjadikan mereka penasaran sehingga sangat mungkin sekali bagi mereka untuk kehilangan arah, sehingga pada akhirnya terjerumus pada jalan yang salah atau menyimpang. Perilaku menyimpang diartikan suatu perilaku yang tidak sesuai dengan nilai dan norma yang terdapat di lingkungan masyarakat, dilakukan secara perorangan ataupun secara berkelompok (Astuti, 2015).

Penyimpangan perilaku pada remaja dapat juga disebut dengan kenakalan remaja. Dalam perspektif perilaku menyimpang merupakan masalah sosial yang terjadi karena terdapat penyimpangan perilaku dan berbagai aturan-aturan sosial ataupun dari nilai dan norma sosial yang berlaku dan diekpresikan oleh seorang atau lebih dari anggota masyarakat, baik disadari ataupun tidak disadari (Kartono, 2010). Berdasarkan riset yang dilakukan oleh Mantiri (2014) perilaku menyimpang yang sering terjadi pada anak usia remaja seperti mengkonsumsi alkohol, merokok, balapan liar, mencuri, membaca atau menonton video porno, seks di luar nikah, menggunakan obat narkotika menghirup lem, bahkan melakukan tindak kekerasan dan lainnya.

Riset yang dilakukan Komisi Perlindungan Anak Indonesia (KPAI, 2016) pada tahun 2015 ditemukan 113 kasus anak korban tayangan dan pergaulan seks bebas, 74 kasus anak sebagai pengguna NAPZA dan 31 kasus anak sebagai pengedar. Kasus anak yang terlibat perkelahian antar pelajar berjumlah 222 kasus, sedangkan kasus anak dengan 
pornografi dan cyber crime sebanyak 463 kasus. Kasus anak yang melakukan kekerasan seksual (pemerkosaan, pencabulan, sodomi/pedofilia, dan sebagainya) 157 kasus, anak yang melakukan pencurian berjumlah 81 kasus, anak yang melakukan pembunuhan berjumlah 36 kasus, dan anak yang melakukan tindak kekerasan (penganiayaan, pengeroyokan, perkelahian, dan sebagainya) berjumlah 81 kasus.

Perilaku-perilaku menyimpang tersebut terjadi karena di pengaruhi beberapa faktor penyebab, diantaranya pernah menjadi korban, pengaruh lingkungan, libido yang tidak terkontrol, kebutuhan perhatian yang kurang dari keluarga atau kedua orang tua, kebutuhan ekonomi yang tidak mencukupi, narkoba dan alkohol (Magdalena, 2010). Perkembangan zaman yang cepat juga membawa perubahan dan pergeseran nilai yang drastis sehingga menjadi penyebab meningkatnya ketidaknormalan di dalam lingkungan masyarakat. (Saifuddin, 2015). Hal tersebut juga dipengaruhi oleh budaya luar, melalui tontonan, bacaan, dan internet sehingga memiliki pengaruh yang besar dalam pembentukan karakter, perilaku serta persepsi pada remaja (Hasan, Boham dan Rembang, 2016).

\section{Persepsi merupakan proses} menyimpulkan informasi dan menafsirkannya secara otomatis berdasarkan pengalaman ataupun peristiwa-peristiwa yang terjadi terhadap suatu objek (Notoatmodjo, 2010). Berdasarkan penelitian yang dilakukan oleh
Dira (2016) tentang persepsi siswa SMAN 1 Payung tehadap kenakalan remaja, dengan metode penelitian survei menggunakan kuesioner dan dianalisis secara deskriptif, sehingga mendapatkan gambaran umum tentang persepsi kenakalan remaja dengan hasil penelitian ini menunjukkan bahwa persepsi siswa terhadap kenakalan remaja menilai lebih negatif dari positif, sekitar $80 \%$ : $20 \%$.

Penelitian yang dilakukan oleh Siska (2013) di SMA Tri Bhakti Pekanbaru. Dari 49 responden memberikan pernyataan 18 orang anak (37,88\%) menjawab sering terjadi kenakalan siswa. Sedangkan 16 orang anak (31,25\%) menjawab kadang - kadang terjadi kenakalan siswa dan 15 orang anak $(30,87 \%)$ menjawab tidak pernah nakal di sekolah.

Berdasarkan studi pendahuluan yang peneliti lakukan pada 23 Mei 2017 dengan mewawancarai Guru Bimbingan Konseling (BK), mengatakan bahwa perilaku siswa dan siswi di dalam sekolah tidak terlalu menonjol akan tetapi pihak sekolah tidak tahu perilaku siswa dan siswinya di luar sekolah. Peneliti juga menggali informasi dengan 3 siswa kelas $\mathrm{X}$, mereka mengatakan bahwa pergaulan beberapa siswa ada yang sering pergi ke tempat hiburan malam, pernah mengalami perkelahian di dalam sekolah antara kelas $\mathrm{X}$ dengan kelas XI, dan pernah juga mengalami perkelahian di luar sekolah. Siswa tersebut juga menyatakan bahwa kejadian seperti itu tidak disampaikan kepada pihak guru, sehingga jarang sekali informasi tentang 
Zulkhairi $^{1}$, Arneliwati ${ }^{2}$, Sofiana Nurchayati $^{3}$,Studi Deskriptif Kualitatif: Persepsi Remaja Terhadap Perilaku Menyimpang

pergaulan menyimpang siswa di luar sekolah atau yang bersifat pribadi terdata oleh pihak sekolah.

Berkaitan dengan latar belakang diatas maka peneliti tertarik untuk memahami gambaran mengenai persepsi remaja tentang perilaku menyimpang dengan teknik mewawancara, agar ungkapan remaja remaja lebih jujur dan menggambarkan apa yang ada dalam persepsi mereka.

\section{METODOLOGI PENELITIAN}

Desain penelitian merupakan rencana penelitian yang disusun sedemikian rupa, sehingga peneliti dapat memperoleh jawaban terhadap pertanyaan penelitian. (Setiadi, 2013). Penelitian ini menggunakan desain penelitian deskriptif kualitatif. Menurut Sukmadinata (2011), penelitian deskriptif kualitatif ditujukan untuk mendeskripsikan dan menggambarkan fenomena-fenomena yang ada, baik bersifat alamiah maupun rekayasa manusia, yang lebih memperhatikan mengenai karakteristik, kualitas, keterkaitan antar kegiatan. Analisa data dalam penelitian ini menggunakan analisa interaktif Miles dan Huberman.

\section{HASIL PENELITIAN}

\section{Karakteristik Responden}

Partisipan yang berpartisipasi dalam penelitian ini ada sebanyak 4 orang, 2 orang siswa kelas XI dan 2 orang siswi kelas XII SMA Tri Bhakti Pekanbaru. Usia partisipan dalam penelitian ini adalah 17 tahun dan 18 tahun. Untuk lebih jelasnya dapat dilihat pada tabel di bawah ini:

Tabel 1

\section{Karakteristik responden}

\begin{tabular}{lcc}
\hline Nomor partisipan & Umur & Kelas \\
\hline 1 & 17 th & XI \\
2 & 17 th & XI \\
3 & 18 th & XII \\
4 & 17 th & XII \\
\hline
\end{tabular}

\section{Hasil Penelitian}

Penelitian ini merupakan penelitian deskripsi kualitatif yang bertujuan untuk mengetahui gambaran persepsi remaja terhadap perilaku menyimpang yang dilakukan di SMA Tri Bhakti pekanbaru. Untuk mengetahui bagaimana persepsi remaja terhadap perilaku menyimpang, peneliti melakukan penelitian sesuai dengan tahaptahap yang telah dijelaskan pada bab sebelumnya. Adapun hasil wawancara secara umum yang peneliti temui dapat peneliti uraikan sebagai berikut.

\section{Persepsi remaja terhadap perilaku menyimpang}

Setelah dilakukan analisa data dari keempat partisipan yang diwawancarai semua partisipan sependapat bahwa perilaku menyimpang itu merupakan perilaku yang tidak baik. Semua partisipan berpersepsi negatif terhadap perilaku menyimpang yang sering terjadi pada usia remaja.

Berikut ungkapan dari partisipan:

”...kan kalau perilaku yang kayak gitu kan ngak bagus bang... dapat merugikan diri sendiri dan orang lain” (Pl).

“...saya sebenarnya prihatin dan sedih. Seharusnya kita sebagai anak muda itu bisa mengembangkan lagi generasi muda 
ini, tapi kok malah begini gitu... malah memprihatinkan" (P2).

“...perilaku menyimpang tu ya... perilaku yang tidak baik atau negatif...” (P3).

“...yang terfikirkan... yaaa... kenapa sekarang jadi kayak gitu bang... apa... lebih sering kayak yang negatif gitu lah" (P4).

Hasil analisa data dari keempat partisipan memberikan gambaran bahwa fenomena perilaku menyimpang saat sekarang ini berdasarkan dari sudut pandang partisipan sebagai seorang remaja, perilaku menyimpang merupakan perilaku yang tidak baik dan memprihatinkan, dapat merugikan diri sendiri dan orang lain, serta bersifat negatif.

\section{Bentuk-bentuk dari perilaku menyimpang}

Hasil wawancara dari keempat partisipan tentang bentuk-bentuk perilaku menyimpang yang umum terjadi pada remaja didapatkan seluruh partisipan mampu menyebutkan bentuk-bentuk perilaku menyimpang. Agar lebih mudah memahami pada bentuk-bentuk perilaku menyimpang, peneliti menspesifiknya menjadi dua kelompok jenis perilaku menyimpang.

Berikut adalah bentuk perilaku menyimpang yang diungkapkan partisipan:

a) Tindakan nonconform

Contoh tindakan nonconform seperti merokok di tempat-tempat yang dilarang.

Berikut ungkapan dari partisipan:

“...kalau disekolah tu bang... apa... merokok di wc” (PI).
“...Merokok... merokok banyak jugak, misalnya di sekolah saya banyak juga merokok di lingkungan sekolah, kadang waktu keluar main... apa... siswa siswa yang agak nakal dia pergi ke-wc melakukan hal-hal yang tidak baik seperti merokok"(P2).

b) Tindakan anti sosial atau asosial

Contoh bentuk tindakan antisosial atau asosial seperti penyalahgunaan narkotika, perkelahian antar pelajar, pergaulan bebas dan seks bebas, dan sebagainya.

Berikut ungkapan partisipan :

“...pergaulan bebas, narkoba, geng motor... kalau remaja biasanya bang tawuran bang" (P1).

“...tawuran. Eeem... minuman keras... pergaulan bebas... itu seperti nantik banyak anak-anak geng motor gitu, mereka melakukan tindakan-tindakan kriminal di jalanan atau di tempat umum. Minum-minuman keras... kebanyakan anak-anak sekarang jugak banyak yang narkoba juga kan... banyak yang narkoba," (P2)

“...penyalahgunaan narkotika... eeee seks bebas, itu masuk tu?... apa lagi yaa ... yaa itu" (P3)

“... ya kayak mengenal dunia malam gitu, dunia malam, terus pergaulan bebas terus seks ya... ya kayak gitu lah. Selain itu ya penyalahgunaan... eeem... penyalahgunaan obat-obatan gitulah" (P4).

Hasil analisa dari keempat partisipan pada bentuk tindakan perilaku menyimpang, untuk tindakan nonconform terdapat 2 orang dari 4 partisipan menyebutkan merokok merupakan perilaku menyimpang yang dilakukan remaja di lingkungan sekolah. 
Zulkhairi', Arneliwati ${ }^{2}$, Sofiana Nurchayati $^{3}$,Studi Deskriptif Kualitatif: Persepsi Remaja Terhadap Perilaku Menyimpang

Sedangkan untuk perilaku menyimpang antisosial atau asosial seluruh partisipan mampu menyebutkan dan memberikan contoh seperti penyalahgunaan narkoba, pergaulan bebas, minum-minuman keras, perkelahian antar pelajar atau tawuran, geng motor yang melakukan tindakan merugikan masyarakat (tindakan-tindakan kriminal dan ugal-ugalan di jalanan).

\section{Faktor-faktor penyebab remaja melakukan perilaku menyimpang}

Dari hasil wawancara yang dilakukan kepada keempat partisipan, seluruh partisipan mengungkapkan faktor penyebab seorang remaja mau melakukan perilaku menyimpang.

Berikut ungkapan dari partisipan :

“...kalau menurut saya bang... faktor utama tu ya, kurang perhatiannya orang tua bang... yang kedua tu bisa... apa... pengaruh lingkungan... tu kawan-kawan sepermainan ... itulah bang” (Pl).

“...tu... faktor terpentingnya tu berawal dari pergaulannya yang salah... pergaulan... pergaulan bebas... memilih teman asal-asal memilih teman saja tidak difikirkan baik atau buruknya... kurang perhatiannya orang tua... sangat penting peng... perhatian orang tua karena keluarga adalah eeee... pokoknya dari apa... inti dari kesopanan, itu mungkin bisa dibilang itu nomor satu keluarga... keluar... yang mendidik keluarga..." kurangnya ilmu agama jugak (P2).

“...bisa jadi orang tua... ia kan tu banyak orang tuanya bilang kayak gini jadi dia nya ngambil kesini gitu... yang yang kayak broken home gitu bang... dihasut teman... pengaruh teman... itu bang... bisa jadi karena melihat ituu... apa?... melihat orang gitukan" (P3). “...yaa dari lingkungannya bang terus dari teman-temannya jugak terus bisa jadi dari keluarga yang agak ada masalah gitu.. yaa.. gara-gara ingin mengetahui gimana rasanya" (P4).

Analisa dari hasil wawancara yang mendalam dengan partisipan, berdasarkan sudut pandang dari partisipan didapatkan hasil beberapa faktor penyebab seorang remaja mau melakukan perilaku menyimpang. Partisipan memahami faktor penyebab perilaku menyimpang pada remaja yaitu akibat dari kurang perhatian orang tua atau akibat dari broken home serta karena pengaruh temanteman dekat mereka dan lingkungan pergaulan yang tidak baik atau terlalu bebas, rasa ingin tahu dan kurangnya ilmu agama.

\section{Dampak dari perilaku menyimpang}

Hasil persepsi dari ke empat partisipan dampak dari perilaku menyimpang yaitu ada dampak fisik, dampak psikologis dan dampak sosial. Beberapa partisipan memiliki pernyataan yang sama dari pada subtema tertentu.

Berikut ungkapan partisipan tentang dampak dari perilaku menyimpang:

a) Dampak fisik

Perilaku menyimpang berdampak pada fisik seseorang, dampak fisik yang terjadi akibat perilaku menyimpang menurut persepsi partisipan adalah luka fisik akibat perkelahian dan merusak kesehatan paru-paru akibat rokok. Berikut adalah ungkapan partisipan :

“...misalnya kalo tawuran kan bang main senjata tajam itu kan dapat merusak diri bang, ha tu lah bang dapat merusak diri... misalnya kenak sabitan senjata 
tajam... eem kan merusak diri tu bang... luka... misalnya rokok kan bang itu kan berbahaya bagi kesehatan terutama paruparu kan bang... ada zat nikotin tar nya itu bang... misalnya geng motor itukan balap-balapan di jalan-jalan tu bang, tu kan kalo apakan bang... terjatuh tu kan bisa mengakibatkan kematian, patah kaki.. itulah bang" (P1).

“...tawuran... ee tawuran berdampak negatif bagi kita karena... terhadap fisik... tubuh kita jadi apa gitu... kelainan, bisa jadi kelainan... ha misalnya patah tulang gitu karena tawuran, misalnya dipukul lawan" (P2).

“...orang merokok, dapat merusak kesehatan paru-parunya” (P3).

Berdasarkan hasil analisa wawancara, dampak secara fisik dari perilaku menyimpang, partisipan hanya mencontohkan beberapa perilaku menyimpang saja. Dampak secara fisik yang terjadi menurut partisipan yaitu luka fisik akibat dari perkelahian antar pelajar atau tawuran dan merusak kesehatan paru-paru akibat rokok.

b) Dampak psikologis

Perilaku menyimpang berdampak pada psikologis seseorang, dampak psikologis yang terjadi akibat perilaku menyimpang menurut persepsi partisipan adalah tidak fokus atau fikiran jadi terganggu akibat minuman keras dan narkoba dan candu akibat menggunakan obat-obatan yang berbahaya. Berikut adalah ungkapan partisipan :

“...misalnya minuman keras itu bang kan dapat mengaggu apa tu bang... hilangnya kesadaran ee.. itulah... fikiran kita jadi terganggu bang” (P1). “...contohnya narkoba, itu dampak psikologisnya bisa... fikiran menjadi.. terombang- ambing tidak fokus karena narkoba mengandung zat-zat berbahaya jugak" (P2).

“...psikologis... jiwanya... kalo... bisa jadi gila... karena ngak dapat obat” (P3).

“...yaa... menyalahgunakan... guna.. kayak dari obat-obat... jadi fikiran candu terus" (P4).

Berdasarkan hasil analisa wawancara pada dampak psikologis dari perilaku menyimpang menrut partisipan adalah menganggu proses berfikir seseorang seperti kurang fokus.

c) Dampak sosial

Perilaku menyimpang berdampak pada hubungan sosial seseorang, dampak terhadap sosial yang terjadi akibat perilaku menyimpang menurut persepsi partisipan adalah dihindari atau diasingkan oleh masyarakat dan teman-teman.

Berikut adalah ungkapan partisipan :

“...di lingkungan rumah itu kan bang kita pastilah udah dijauhi oleh masyarakat bang... kalau di lingkungan sekolah yaa... dijauhi teman-teman lah bang, misalnya kita sukak mencuri ya kan bang, merokok... pastilah kita dijauhi sama teman-teman di sekolah... menjauh dari kita" (P1).

“...menurut saya berdampak negatif... si pelaku dijauhi oleh masyarakat dan tidak dipedulikan masyarakat karena si pelaku ini melakukan hal-hal yang itu tadi keluar dari norma-norma dan nilai-nilai masyarakat" (P2).

“...malu.. dia ngak dipandang orang.. kalau dia melakukan penyimpangan dia 
Zulkhairi', Arneliwati ${ }^{2}$, Sofiana Nurchayati $^{3}$,Studi Deskriptif Kualitatif: Persepsi Remaja Terhadap Perilaku Menyimpang

ngak dipandang orang... dia dianggap itu ya... dianggap gimana yaa.. ia pokoknya dia ngak ditengok orang gitu... pokoknya seperti itu.. eeeeem gimana ya... ngak dilihat gitu, ngak di acuhkan orang dalam lingkungan masyarakat... dia ngak terlalu itu” (P3).

“...dampaknya ... dia jadi terhindar gitu... disisihkan” (P4).

Berdasarkan hasil analisa dari wawancara dengan partisipan didapatkan beberapa dampak yang ditimbulkan dari perilaku menyimpang. Partisipan memahami dampak sosial yang yang ditimbulkan akibat perilaku menyimpang yaitu dihindari atau diasingkan oleh masyarakat dan teman-teman.

\section{PEMBAHASAN}

\section{A. Interpretasi hasil}

\section{Persepsi remaja terhadap perilaku menyimpang}

Penelitian pada persepsi remaja terhadap perilaku menyimpang, dari keempat partisipan tidak mendukung perilaku menyimpang. Semua partisipan berpersepsi negatif terhadap perilaku menyimpang yang terjadi pada remaja saat ini. Hasil penelitian ini didukung oleh hasil penelitian Dira (2016) menunjukkan bahwa persepsi siswa terhadap kenakalan remaja menilai lebih negatif dari positif, sekitar $80 \%: 20 \%$.

Penyimpangan perilaku pada remaja dapat juga disebut dengan kenakalan remaja. Dalam perspektif perilaku menyimpang merupakan masalah sosial yang terjadi karena terdapat penyimpangan perilaku dan berbagai aturan-aturan sosial ataupun dari nilai dan norma sosial yang berlaku dan diekpresikan oleh seorang atau lebih dari anggota masyarakat, baik disadari ataupun tidak disadari (Kartono, 2010).

Kesimpulan dari tema tentang persepsi remaja terhadap perilaku menyimpang berdasarkan analisa yang peneliti lakukan bahwa seluruh partisipan dalam penelitian ini menyatakan bahwa perilaku menyimpang merupakan perilaku yang tidak baik, dapat merugikan diri sendiri dan orang lain serta suatu perilaku yang negatif.

\section{Bentuk-bentuk dari perilaku menyimpang}

Penelitian ini partisipan mampu mengungkapkan bentuk-bentuk atau contohcontoh perilaku menyimpang yang terjadi pada remaja. Bentuk-bentuk perilaku menyimpang yang terdapat pada hasil penelitian ini adalah merokok, konsumsi minuman keras atau mabuk-mabukan, penyalahgunaan narkoba, seks bebas, perkelahian antar pelajar dan pergaulan bebas. Hasil penelitian dari tema ini didukung oleh penelitian yang dilakukan oleh Mantiri (2014), bentuk-bentuk perilaku menyimpang pada remaja-remaja seperti mengkonsumsi minum-minuman keras atau mabuk-mabukan, merokok, seks diluar nikah, penyalahguna narkotika.

Hasil penelitian pada tema ini juga didukung oleh teori Narwoko dan Suyanto (2007) mengatakan bahwa terdapat penggolongan bentuk perilaku menyimpang kalangan ramaja antara seperti tindakan 
nonconform yaitu perilaku yang tidak sesuai dengan nilai-nilai atau norma-norma yang ada. Contoh tindakan nonconform seperti membolos atau meninggalkan pelajaran pada jam-jam sekolah, merokok di area yang dilarang merokok dan sebagainya. Sedangkan perilaku menyimpang seperti mengkonsumsi minum-minuman keras, penyalahgunaan narkoba serta melakukan seks diluar nikah merupakan bagian dari tindakan perilaku menyimpang dari segi antisosial ataupun asosial.

Soetjiningsih (2004) dalam buku tumbuh kembang remaja dan permasalahannya menjelaskan bahwa, pada masa remaja sering didapatkan adanya gangguan tingkah laku (conduct disorder) yang melanggar normanorma sosial yang berlaku. Semakin banyak pula remaja yang ditahan karena melakukan tindakan kriminalitas yang digolongkan sebagai kenakalan remaja (junevile delinquent). Penyimpangan perilaku yang biasanya terjadi pada remaja remaja seperti menggunakan obat-obatan terlarang, melakukan hubungan seks secara bebas tanpa perlindungan, pornografi, pencopetan dan bahkan melakukan perampokan bersenjata.

Siska (2013) dalam penelitiannya menyebutkan indikator-indikator kenakalan remaja diantaranya yaitu perkelahian, bolos atau cabut, merokok, geng sekolah, tindak kriminal, menimum minuman keras, dan pornografi. Supriana, Rohimat dan Kosim (2006) membagi bentuk perilaku menyimpang menjadi empat macam yaitu kejahatan atau kriminalitas, penyimpangan seksual, penyalahgunaan narkoba dan penyimpangan dalam bentuk gaya hidup.

Kesimpulan dari tema ini berdasarkan dari analisa peneliti terhadap pernyataan partisipan dan penelitian terkait, partisipan hanya menyebutkan beberapa bentuk perilaku menyimpang seperti merokok, konsumsi minuman keras atau mabuk-mabukan, penyalahgunaan narkoba, seks bebas, perkelahian antarpelajar dan pergaulan bebas.

\section{Faktor-faktor penyebab remaja melakukan perilaku menyimpang}

Penelitian ini partisipan mampu mengungkapkan faktor-faktor yang menyebabkan dan mempengaruhi remaja melakukan perilaku menyimpang. Beberapa faktor penyebab yang partisipan ungkapkan adalah akibat dari kurang perhatian orang tua, broken home, pengaruh teman-teman dekat mereka dan lingkungan yang tidak baik, rasa ingin tahu dan kurangnya ilmu agama.

Tema penelitian ini didukung oleh penelitian yang lakukan Darmasih (2009) dari hasil penelitian tentang faktor yang mempengaruhi perilaku seks pranikah pada rmaja didapatkan bahwa ada pengaruh pengetahuan, pemahaman tingkat agama, sumber informasi, dan peranan keluarga terhadap perilaku seks pranikah pada remaja SMA di Surakarta.

$$
\text { Penelitian Widiansyah }
$$

didapatkan banyak faktor-faktor yang menyebabkan remaja Sidorejo merokok, yaitu ada empat faktor antara lain keperibadian 
Zulkhairi $^{1}$, Arneliwati ${ }^{2}$, Sofiana Nurchayati $^{3}$,Studi Deskriptif Kualitatif: Persepsi Remaja Terhadap Perilaku Menyimpang

remaja tersebut, apektif, linglungan dan pengaruh media iklan. Seperti halnya mereka merokok atas dasar keinginan mereka sendiri untuk mencoba merokok, biasanya remaja ini belajar dengan cara mengambil rokok orang tua mereka secara sembunyi ataupun membeli dengan uang saku mereka, masa remaja adalah masa dimana remaja sangat ingin tau dan ingin mencoba hal-hal yang belum pernah dirasakan, seperti halnya merokok. Selain karena dorongan diri sendiri pengaruh merokok juga dipengaruhi oleh teman sepermainan maupun sekolah, dengan seringnya berkumpul dan melakukan aktifitas bersama-sama secara tidak langsung menimbulkan rasa persatuan diantara mereka, sehingga apabila ada salah satu mereka merokok dengan mudah mempengaruhi remaja lain untuk mencoba merokok.

Dhohiri., dkk (2007) menyebutkan beberapa faktor penyebab terjadinya perilaku menyimpang antara lain, ketidakharmonisan dalam keluarga, pelampiasan rasa kecewa, pengaruh lingkungan, keinginan untuk dipuji. Pernah menjadi korban, pengaruh lingkungan, libido yang tidak terkontrol, kebutuhan perhatian yang kurang dari keluarga atau kedua orang tua, kebutuhan ekonomi yang tidak mencukupi, narkoba dan alkohol (Magdalena, 2010).

Teori dalam buku Soetjiningsih (2004) menyebutkan bahwa faktor kejadian gangguan tingkahlaku dan kenakalan remaja cenderung meningkat pada keadaan: sosial ekonomi rendah, pengangguran, percaya diri yang rendah, konflik keluarga, gangguan belajar di sekolah, terlibat dalam gang, ketidakharmonisan di sekolah dan lingkunganya, kurangnya perasaan memiliki, kurangnya pengasuhan orang tua, riwayat keluarga peminum alkohol, melakukan tindakan kriminal atau gangguan psikiatri, riwayat mengalami pengaiayaan fisik atau seksual, dan lain-lain.

Faktor yang mempengaruhi terjadinya perilaku menyimpang dikalangan remaja dalam penelitian Mantiri (2014) adalah faktor dari lingkungan keluarga, faktor dari lingkungan sekolah sekolah, faktor dari lingkungan masyarakat, pengaruh kelompok bermain dan paparan media masa.

Berdasarkan analisa peneliti dari pernyataan partisipan serta penelitian dan teori terkait dapat disimpulkan bahwa menurut partisipan faktor-faktor yang mempengaruhi dan menjadi penyebab seorang remaja melakukan tindakan perilaku menyimpang adalah akibat dari kurang perhatian orang tua, broken home, pengaruh teman-teman dekat mereka dan lingkungan yang tidak baik, rasa ingin tahu dan kurangnya ilmu agama

\section{Dampak dari perilaku menyimpang}

Penelitian ini partisipan mampu mengungkapkan dampak yang ditimbulkan dari perilaku menyimpang. Baik dampak fisik, dampak psikologis dan dampak secara sosial.

a) Dampak secara fisik

Dalam subtema ini dampak yang disebutkan oleh partisipan hanya dari beberapa contoh perilaku menyimpang saja seperti 
perilaku tawuran atau perkelahian antar pelajar dampak yang ditimbulkan luka fisik. Kemudian pada subtema ini partisipan juga menjelaskan dampak dari perilaku merokok yaitu merusak kesehatan dari organ paru-paru pelaku.

Subtema di atas dalam tema ini didukung oleh penelitian yang dilakukan oleh oleh hasil penelitian yang dilakukan oleh Arizal (2013), dampak secara fisik dari perkelahian antar siswa meliputi kerugian dibeberapa bidang, yaitu kerusakan fisik, kerugian materil, dan terganggunya ketentraman sosial. Adanya siswa yang takut berangkat sekolah karena takut ditengah jalan ada pihak musuh yang menghadangnya.

Terpaparnya asap rokok selama 8 jam sebanding dengan merokok langsung sebanyak 20 batang perhari. Konsekuensi dari merokok antar lain meningkatnya kejadian infeksi saluran napas bagian atas, batuk, asma, sinusitis, penyakit kardiovaskular, kanker, menganggu fertilitas, lahir kurang bulan, kematian ataupun absen dari kerja atau sekolah. Anak dan kaum muda yang merokok, pertumbuhan dan perkembangan parunya segera akan terpengaruh oleh asap rokok tersebut (Soetjiningsih, 2004).

b) Dampak secara psikologis

Dalam subtema ini dampak yang disebutkan oleh partisipan hanya dari beberapa contoh perilaku menyimpang saja seperti perilaku minum minuman keras dampak yang ditimbulkan fikiran menjadi terganggu. Kemudian pada subtema ini partisipan juga menjelaskan dampak dari perilaku penyalahgunaan narkoba dan obat-obat obatan narkotika adapun dampak yang ditimbulkan menurut partisipan adalah candu atau ketagihan.

Subtema di atas dalam tema ini didukung oleh penelitian yang dilakukan oleh Adam (2012), dampak psikologi dari penggunaan narkoba yang ditimbulkan adalah, ceroboh kerja, sering tegang dan gelisah, hilang kepercayaan diri, apatis, pengkhayal, penuh curiga, agitatif, menjadi ganas dan tingkah laku yang brutal, sulit berkonsentrasi, perasaan kesal dan tertekan, cenderung menyakiti diri, perasaan tidak aman, bahkan bunuh diri, gangguan mental, anti-sosial dan asusila, dikucilkan oleh lingkungan dan kecanduan.

Alkohol merupakan depresan sistem SSP (Sistem Saraf Pusat), namun pada dosis rendah dapat bersifat sebagai stimulan, pada dosis sedang dapat menyebabkan sedasi, euforia, mudah terangsang, dan gangguan koordinasi. Apa bila dosis dinaikkan akan terjadi ataksia, emosi labil, dan bicara yang kacau. Sedangkan pada dosis tinggi dapat menyebabkan penurunan kesadaran, gagal napas, koma dan kematian (Soetjiningsih, 2004).

\section{c) Dampak secara sosial}

Dampak secara sosial dari perilaku menyimpang yang partisipan ungkapkan adalah dihindari atau diasingkan oleh masyarakat di lingkungan masyarakat atau teman-teman di sekolah. Subtema dalam tema 
Zulkhairi $^{1}$, Arneliwati ${ }^{2}$, Sofiana Nurchayati $^{3}$,Studi Deskriptif Kualitatif: Persepsi Remaja Terhadap Perilaku Menyimpang

ini sejalan dengan teori Waluya (2009) yang menyebutkan pada lingkungan sosial, umumnya menimbulkan stigma atau aib sosial bagi pelakunya. Masyarakat memandang pelaku penyimpangan sosial secara negatif sehingga masyarakat mengasingkan pelaku.

Kesimpulan dari sub-subtema ini berdasarkan dari analisa peneliti terhadap pernyataan partisipan dan penelitian terkait serta teori yang mendukung, bahwa seluruh partisipan menyebutkan dampak perilaku menyimpang secara fisik, psikologis dan sosial berdasarkan contoh-contoh yang mereka sebutkan, seperti merokok berdampak pada kesehatan paru-paru perokok tersebut, penggunaan narkoba dan mengkonsumsi minuman keras dapat menganggu proses berfikir seseorang, kurang fokus dan kecanduan, sedangkan pada lingkungan sosial pelaku cenderung diasingkan.

\section{SIMPULAN}

Berdasarkan hasil penelitian tentang gambaran persepsi remaja terhadap perilaku menyimpang di SMA Tri Bhakti Pekanbaru dapat disimpulkan bahwa seluruh partisipan memberikan gambaran tentang fenomena perilaku menyimpang saat sekarang ini berdasarkan dari sudut pandang partisipan sebagai seorang remaja, perilaku menyimpang merupakan perilaku yang tidak baik dan memprihatinkan, dapat merugikan diri sendiri dan orang lain, atau bersifat negatif. Partisipan juga memiliki pengetahuan yang baik terhadap perilaku menyimpang.

\section{SARAN}

Diharapkan kepada tenaga kesehatan dan tenaga pendidikan dapat bertanggung jawab memberikan edukasi terkait dengan perilaku menyimpang pada remaja melalui programprogram pendidikan serta masyarakat dapat berpartisipasi dalam menjaga pergaulan remaja di lingkungan sosial masyarakat.

\section{DAFTAR PUSTAKA}

Adam, S. (2012). Dampak Narkotika pada Psikologi dan Kesehatan Masyarakat. Jurnal Health and Sport, 5(2).

Al-Bahra \& Efgivia, G. (2012). Dampak Pergaulan Bebas dan Solusinya

Arizal, Y. (2013). Kajian Psikososial terhadap Fenomena Perkelahian antar Siswa. Jurnal BK UNESA, 1(1).

Astuty, T. (2015). Sosiologi : Ranan Inti Sari Sosiologi Lengkap. Jakarta: Vicosta Publishing

Darmasih, R. (2009). Faktor yang mempengaruhi perilaku seks pranikah pada remaja SMA di Surakarta. Doctoral dissertation, Universitas Muhammadiyah Surakarta).

Dhohiri, T.R. (2007). Sosiologi : Suatu Kajian Kehidupan Masyarakat.. ( $3^{\text {th }}$ ed). Jakarta: Yudhistira

Dinas Kesehatan Kota Pekanbaru. (2014). Profil Kesehatan Kota Pekanbaru 2014. Diperoleh tanggal 29 April 2017, dari: http://www.pusdatin.kemkes.go.id/resourc es/download/profil/PROFIL_KAB_KOTA _2014/1471_Riau_Kota_Pekan_Baru_20 14.pdf

Dinas Kesehatan Provinsi Riau. (2014). Profil Kesehatan Provinsi Riau 2014. Diperoleh tanggal 29 April 2017, dari: https://www.google.com/url? $s a=t \& r c t=j \& q=\&$ esr $c=s \&$ source $=w e b \&$ $c d=2 \& c a d=r j a \& u a c t=8 \& v e d=0 a h U K E w$ j87pTE3oXUAhVJNY8KHcE7COcQFggk $M A E \& u r l=h t t p \% 3 A \% 2 F$ $\% 2$ Fdinkesriau.net

Dira, S. (2017). Persepsi Siswa Sman 1 Payung Tehadap Kenakalan Remaja. 
Studia, 1(1), 107-124.

Hasan, R., Boham, A., \& Rembang, M. (2016). Peran orang tua dalam menginformasikan pengetahuan seks bagi remaja di desa Picuan kecamatan Motoling Timur kabupaten Minahasa selatan. Jurnal Acta Diurna, 5(3).

Kartono, K. (2010). Kenakalan Remaja, Patologi Sosial 2. Jakarta: Raja Grafindo Persada

Kementererian Kesehatan Republik Indonesia. (2016). Artikel: Profil Kesehatan Indonesia 2015. Diperoleh tanggal 2 Februari 2017, dari: http://www.pusdatin.kemkes.go.id/resourc es/download/pusdatin/profil-kesehatanindonesia/Profil-Kesehatan-I-2015Lampiran.pdf

KPAI. (2016). Rincian Tabel Kasus Pengaduan Anak Berdasarkan Klaster Perlindungan Anak, Komisi Perlindungan Anak Indonesia Tahun 2011 - 2016. Diperoleh tanggal 28 April 2017, dari: http://www.ucarecdn.com/99c9dbd10168-4afc-9224-29095099bcc2/.

Magdalena, M. (2010). Melindungi anak dari seks bebas. Jakarta: Grasindo

Mantiri, V. V. (2014). Perilaku menyimpang di kalangan remaja di Kelurahan Pondang, Kecamatan Amurang Timur Kabupaten Minahasa Selatan. Journal Volume III (1).

Sukmadinata, N. S. (2011). Metode penelitian pendidikan. Bandung: PT Remaja Rosdakarya.

Narwoko, J. D \& Suyanto, B. (2007). Sosiologi: teks pengantar dan terapan. Jakarta: Kencana

Notoatmodjo, S. (2010). Metode ilmu pengetahuan dalam metodelogi penelitian kesehatan. Jakarta: PT Rineka Cipta

Saifuddin, A. (2015). Abnormalitas perilaku pada anak dan remaja, sudah sebegitu parahnya?

Sarwono, S.W. (2014). Pengantar psikologi umum. Jakarta: Rajawali Pers
SDKI. (2013). Survei Demografi dan Kesehatan Indonesia 2012, Kesehatan Reproduksi Remaja. Diperoleh tanggal 27 April 2017 dari http://kesga.kemkes.go.id/ images/pedoman/SDKI-2012-RemajaIndonesia.pdf

Setiadi. (2013). Konsep dan praktik penulisan riset keperawatan Edisi 2. Yogyakarta: Graha ilmu.

Siska, L. (2013). Peran Kerjasama Sekolah dan Orang Tua dalam Mengatasi Kenakalan Remaja di SMA Tri Bhakti Pekanbaru.

Soetjiningsih. (2004). Tumbuh kembang remaja dan permasalahannya. ( $\left.1^{\text {th }} \mathrm{ed}\right)$. Jakarta: CV. Sagung Seto

Soetjiningsih. (2010). Tumbuh kembang remaja dan permasalahannya. ( $3^{\text {th }}$ ed). Jakarta: CV. Sagung Seto

Supriatna. N, Ruhimat, M \& Kosim. (2007). IPS Terpadu (Sosiologi, Geografi, Ekonomi, Sejarah) Jakarta: PT. Grafindo Media Pratama

Waluya, B. (2009). Sosiologi: menyelami fenomena sosial di masyarakat. Jakarta: Pusat Pembukuan, Departemen Pendidikan Nasional

Widanarti, M., \& Nashori, F. (2015). Pengaruh pendidikan seksual islami terhadap sikap permisif terhadap perilaku seksual pranikah pada remaja. Jurnal Psikologi" Mandiri", 1(2).

Widiansyah, M. (2014). Faktor-faktor penyebab perilaku remaja perokok di desa Sidorejo Kabupaten Penajam Paser Utara. URL: http://ejournal. sos. fisipunmul. ac. $\mathrm{id} /$ site/wpcounten/uploads/2014/10/pe nting, 20, 10-02.

World Health Organisation. (2014). Situasi kesehatan reproduksi remaja. Diperoleh tanggal 7 Mei 2017, dari: http://www.depkes.go.id/resources/downl oad/pusdatin/infodatin/infodatin \%20reproduksi\%20remaja-ed.pdf 